\title{
Effect of Phosphorus and Zinc Solubilizing Acidifiers on Content and Uptake of Micro nutrients in Summer Soybean
}

\author{
B. Kranthi Kumar*, Syed Ismail, K. Manasa and K. Anuradha Pawar \\ Department of Soil Science and Agricultural Chemistry, Vasantrao Naik Marathwada Krishi \\ Vidyapeeth, Parbhani 431 402, Maharashtra, India \\ *Corresponding author
}

\begin{tabular}{|c|c|}
\hline & A B S T R A C T \\
\hline Keywords & \multirow{4}{*}{$\begin{array}{l}\text { The present investigation was carried out during summer season of 2014-15 } \\
\text { on Research farm, Department of Soil Science and Agricultural Chemistry, } \\
\text { Vasantrao Naik Marathwada Krishi Vidyapeeth, Parbhani to evaluate the } \\
\text { effect of different zinc solubilizing microbial cultures on nutrient content } \\
\text { and uptake of soybean grown on Vertisol. Results revealed that highest } \\
\text { Nutrient content and uptake was increased with the inoculation of microbial } \\
\text { cultures as compared to uninoculated control and highest Fe, Mn, Cu, and } \\
\text { Zn uptake was found with the treatment RDF + Rhizobium + Trichoderma } \\
\text { viride. }\end{array}$} \\
\hline $\begin{array}{l}\text { Soybean, } \\
\text { Nutrient content, } \\
\text { Nutrient uptake. }\end{array}$ & \\
\hline Article Info & \\
\hline $\begin{array}{l}\text { Accepted: } \\
\text { 26 May } 2017 \\
\text { Available Online: } \\
\text { 10 June } 2017\end{array}$ & \\
\hline
\end{tabular}

\section{Introduction}

Soybean (Glycine max L. Merrill) a grain legume is considered as a wonder crop due to its dual qualities viz., high protein $(40-43 \%)$ and oil content (20\%). It also contains 60\% poly-unsaturated fatty acid, vitamin-B (300 I.U) and vitamin C, D, E, K. It contains $0.69 \%$ phosphorus, $0.011 \%$ iron, $0.024 \%$ calcium and all other essential amino acids (Rahman, 1982). Major soybean growing states in India are Maharashtra, Madhya Pradesh, Gujarat and Rajasthan. India ranks 5th in area and production of soybean in the world after U.S.A., Brazil, China, Argentina. Soybean has emerged as one of the major oil seed crop in India with the coverage of above 108.8 lakh hectare with estimated production of over 104.36 lakh MT during 2014. In Maharashtra state, soybean crop is grown on an area of 38.08 lakh hectare with total production 30.72 lakh MT with average productivity of $808 \mathrm{~kg} /$ ha (Anonymous, 2014). The poor productivity of soybean is mainly due to imbalance application of nutrients and use of traditional varieties. Under such situations, use of Rhizobium and zinc solubilizing bacteria (ZSB) had shown advantage in enhancing soybean productivity. Microbial inoculants are cost effective, ecofriendly and renewable sources of plant nutrients. Zinc has an immense role in nutrition of both eukaryotic and prokaryotic organisms as cofactor or metal activator in various enzyme systems (Hughes and Poole, 1989). Bacteria are known to immobilize metal by precipitation and adsorption. The ability to dissolve immobilized zinc viz. zinc 
phosphate, zinc oxide and zinc carbonate in appreciable quantity is not common feature amongst the cultivable bacteria on soil surface. Few Zn solubilizing bacterial genera viz. Thiobacillus thioxidans, Thiobacillus ferroxidans, Acinetobacter, Bacillus, Gluconacetobacter, Pseudomonas and facultative thermophilic iron oxidizers have been reported as zinc solubilizers (Saravanan et al., 2007). Because of avoidance of environmental problems, human health, and more crop integrated nutrient management plant beneficial living microbial cultures (biofertilizers) are supposed to be a safe supplement to chemical fertilizers in order to minimize the ecological disturbance. A number of microorganisms are considered as challenging agents for agriculture to promote better nutrient uptake and availability for plant use particularly zinc mobilizing and acidifying cultures may help to increase the zinc and other micronutrients availability for the crops like soybean. Summer soybean has a tremendous potential to be used as seed for kharif season. By considering these points, experiment was carried out to study the effect of zinc solubilizing microbial cultures on yield, nutrient uptake and quality of soybean.

\section{Materials and Methods}

Field experiment was conducted at research farm of Department of Soil Science and Agricultural Chemistry, Vasantrao Naik Marathwada Krishi Vidyapeeth, Parbhani on Vertisol during summer season of 2014-15 on soybean variety MAUS-162. The initial soil $\mathrm{pH}$ was 7.96, EC- $0.28 \mathrm{dSm}-1$, organic carbon-5.26 g kg-1, $\mathrm{CaCO}_{3}-37.0 \mathrm{~g} \mathrm{kg-1}$ available $\mathrm{N}-190 \mathrm{~kg}$ ha- $1, \mathrm{P}_{2} \mathrm{O}_{5}-16.7 \mathrm{~kg}$ ha$1, \mathrm{~K}_{2} \mathrm{O}-580 \mathrm{~kg}$ ha-1 and S-9.42 mg kg-1.

The initial micronutrient status were available Cu 2.27 mg kg-1, Mn 7.22 mg kg-1, Zn 0.56 $\mathrm{mg} \mathrm{kg}-1$, Fe $5.28 \mathrm{mg} \mathrm{kg}-1$.The soil was clayey in texture, low in organic carbon, available nitrogen, medium in phosphorus, sufficient in potassium and low in sulphur. As among the micronutrient status $\mathrm{Cu}, \mathrm{Fe}$ and Mn were above the critical limits but Available $\mathrm{Zn}$ content in experimental soil was found to be deficient. The treatments comprising inoculation with liquid inoculants of BradyRhizobium and Bacillus megaterium (PSB) for soybean, used in alone and in combinations. The experiment was laid out in Randomised Block Design with eight treatments in combinations in three replications. The experiment consisting of 8 treatments of laboratory tested $\mathrm{Zn}$ solubilizers T1: RDF + Rhizobium; T2: RDF + Rhizobium + Burkholderia cepacia; T3: RDF + Rhizobium + Burkholderia cenocepacia; T4: $\mathrm{RDF}+$ Rhizobium + Pseudomonas fluorescens; T5: RDF + Rhizobium + Pseudomonas striata; T6: RDF + Rhizobium + Trichoderma viride; $\mathrm{T} 7: \mathrm{RDF}+$ Rhizobium + Trichoderma harzianum; T8: RDF + Rhizobium + Bacillus megaterium. Seed treatment was done before sowing with liquid bioinoculants each@ @ $50 \mathrm{ml} 10 \mathrm{~kg}^{-1}$ seed. The crop was raised following recommended agronomic practices. The observations were recorded replication wise in each treatment namely number of nodules, fresh and dry weight of nodules, leghaemoglobin content in nodules (Thimmaiah, 2000), protein content (\%) calculated by multiplying the nitrogen (\%) with 5.74 and oil content by soxhlet apparatus (Plummer, 1998).

Protein and oil yield was calculated. Nutrient content $\mathrm{N}$ by Microkjeldhal method (AOAC, 1993), P content determined by spectrophotometrically by Vanadomolybdate phosphoric acid yellow colour method (Jackson, 1967), K content was determined from the diluted diacid extract on flame photometer (Jackson, 1973), S content was estimated by Turbidimetric method from diacid extract (Tabatabai and Bremner, 1970) and micronutrients such as $\mathrm{Zn}, \mathrm{Cu}, \mathrm{Mn}$ and $\mathrm{Fe}$ 
were determined from di-acid extract digest with proper dilution using Atomic Absorption Spectrophotometer with different wavelength (Jackson, 1973). The nutrient uptake was worked out by multiplying the nutrient concentration in plant/grain with respective yields.

All statistical tests were done by RBD design and significant differences was calculated at CD á 0.05 as per the methods described in "Statistical Methods for Agricultural Workers" by Panse and Sukhatme (1985). Uptake $(\mathrm{kg}$ ha-1) = Nutrient content $(\%) \mathrm{x}$ Yields of grain/dry matter (kg ha-1)/ 100

\section{Fe content and uptake in soybean crop}

The data narrated in table 1 indicates that content and Fe Uptake in grain and straw as well as total (grain + straw) by soybean was found highest in treatment $\mathrm{T}_{6}$ (RDF+ Rhizobium + Trichoderma viride) i.e. (545, 557 and $1102.6 \mathrm{~g} \mathrm{ha}^{-1}$ ) respectively followed by treatment $\mathrm{T}_{4}$ (RDF+ Rhizobium + Pseudomonas fluorescens) i.e. (467.6, 504.9 and $972.5 \mathrm{~g} \mathrm{ha}^{-1}$ ) whereas lowest Fe uptake was observed in $\mathrm{T}_{1}$ treatment.

However, $\mathrm{T}_{6}$ was found to be at par with $\mathrm{T}_{4}$ treatment in influencing Fe uptake and lowest Fe grain and uptake was recorded in $\mathrm{T}_{1}$ (RDF + Rhizobium). Chand and Somani (2003) revealed that effective use of FYM, biofertilizers along with chemical fertilizers improved $\mathrm{Fe}$ and $\mathrm{Zn}$ content in mustard. Mekki et al., (1999) reported that organic manure either only or when it associated with biofertilizer increased $\mathrm{Fe}$ concentration in millet cuttings. This increase in Fe is mainly due to the action of biofertilizer that rendered phosphorus and most micronutrients in the available form.

Uptake of $\mathrm{N}, \mathrm{P}, \mathrm{K}, \mathrm{S}, \mathrm{Fe}, \mathrm{Zn}$ and $\mathrm{B}$ to the application of micronutrients especially of Mo @ $1 \mathrm{~kg} \mathrm{ha}^{-1}$ ammonium molybdate which recorded the highest values in case of uptake of all the nutrients. This might be attributed to increased growth of crop under this treatment due to enhanced $\mathrm{N}$ fixation by $\mathrm{Mo}$ and Rhizobium inoculation and also more $\mathrm{P}$ solubilization and uptake due to action of PSB resulting in higher uptake of all other complementary nutrients. Inoculation of biofertilizers (Rhizobium + PSB) also recorded significantly higher uptake of nutrients as against no inoculation (Sarawgi et al., 1999 and Patel, 2003).

\section{Zn content and uptake in soybean crop}

The content and uptake of zinc by soybean was also found to be enhanced significantly with inoculation of Trichoderma viride along with RDF (Table 2).

The data shows increase in $\mathrm{Zn}$ content in grain, straw by soybean crop was recorded higher in treatment $\mathrm{T}_{6}\left(57.8\right.$ and $\left.35.7 \mathrm{mg} \mathrm{kg}^{-1}\right)$ receiving Rhizobium + Trichoderma viride followed by treatment $\mathrm{T}_{4}\left(54.6\right.$ and $32 \mathrm{mg} \mathrm{ha}^{-}$ $\left.{ }^{1}\right)$ treated with Rhizobium + Pseudomonas fluorescens, which were found to be at par with each other and lowest value was noticed in treatment $T_{1}$ and its uptake by grain, straw and total was maximum in treatment $\mathrm{T}_{6}$ receiving $\mathrm{RDF}+$ Rhizobium + Trichoderma viride over other treatments and treatment $\mathrm{T}_{4}$ was found statistically at par with $\mathrm{T}_{6}$.

Amalraj et al.,(2012) studied nutrient solubilization efficiency, plant growth promoting traits and antagonistic effects of Bacillus megaterium var. phosphaticum and revealed that it also improved zinc (184mg/100g dry mass), iron (743mg/100g dry mass) and manganese $(138 \mathrm{mg} / 100 \mathrm{~g}$ dry mass)in plant.

Gurumurthy et al., (2009) noticed the higher uptake of $\mathrm{Zn}$ by soybean with the application of $50 \%$ RDF $-\mathrm{N}+50 \% \mathrm{~N}$ through FYM + PSB in safflower grain and straw. 
Table.1 Effect of phosphorus and zinc solubilizing acidifiers on content and uptake of Fe in summer soybean

\begin{tabular}{|c|l|c|c|c|c|c|}
\hline \multirow{2}{*}{$\begin{array}{c}\text { Sr. } \\
\text { No. }\end{array}$} & \multicolumn{1}{|c|}{ Treatment } & \multicolumn{2}{c|}{$\begin{array}{c}\text { Fe Content } \\
\left.\mathbf{k g}^{-1}\right)\end{array}$} & \multicolumn{3}{c|}{ Fe Uptake $\left(\mathbf{g ~ h a}^{-1}\right)$} \\
\cline { 3 - 7 } & & Grain & Straw & Grain & Straw & $\begin{array}{c}\text { Total } \\
\left(\mathrm{g} \mathrm{ha}^{-1}\right)\end{array}$ \\
\hline $\mathrm{T}_{1}$ & RDF + Rhizobium & 194.0 & 154.0 & 299.5 & 308.0 & 607.0 \\
\hline $\mathrm{T}_{2}$ & $\mathrm{~T}_{1}+$ Burkholderia cepacia & 230.0 & 141.3 & 359.6 & 297.3 & 656.3 \\
\hline $\mathrm{T}_{3}$ & $\mathrm{~T}_{1}+$ Burkholderia cenocepacia & 249.3 & 129.0 & 424.0 & 313.0 & 737.0 \\
\hline $\mathrm{T}_{4}$ & $\mathrm{~T}_{1}+$ Pseudomonas fluorescens & 269.3 & 186.4 & 467.6 & 504.9 & 972.5 \\
\hline $\mathrm{T}_{5}$ & $\mathrm{~T}_{1}+$ Pseudomonas striata & 251.3 & 117.6 & 423.0 & 460.6 & 883.6 \\
\hline $\mathrm{T}_{6}$ & $\mathrm{~T}_{1}+$ Trichoderma viride & 295.0 & 218.0 & 545.6 & 557.0 & 1102 \\
\hline $\mathrm{T}_{7}$ & $\mathrm{~T}_{1}+$ Trichoderma harzianum & 256.0 & 175.6 & 427.0 & 448.6 & 875.6 \\
\hline $\mathrm{T}_{8}$ & $\mathrm{~T}_{1}+$ Bacillus megaterium & 253.6 & 177.3 & 385.5 & 401.0 & 786.6 \\
\hline & S.E. \pm & 2.48 & 18.06 & 26.41 & 22.41 & 37.6 \\
\hline & C.D. at 5 \% & 7.70 & 55.32 & 80.8 & 68.6 & 115.3 \\
\hline & C.V. \% & 6.71 & 13.25 & 10.98 & 9.481 & 7.8 \\
\hline
\end{tabular}

Table.2 Effect of phosphorus and zinc solubilizing acidifiers on content and uptake of $\mathrm{Zn}$ in summer soybean

\begin{tabular}{|c|c|c|c|c|c|c|}
\hline \multirow{2}{*}{$\begin{array}{l}\text { Sr. } \\
\text { No. }\end{array}$} & \multirow{2}{*}{ Treatment } & \multicolumn{2}{|c|}{$\begin{array}{c}\text { Zn Content } \\
\left(\mathrm{mg} \mathrm{kg}^{-1}\right)\end{array}$} & \multicolumn{3}{|c|}{ Zn Uptake (g ha ${ }^{-1}$ ) } \\
\hline & & Grain & Straw & Grain & Straw & $\begin{array}{c}\text { Total (g } \\
\left.\text { ha }^{-1}\right)\end{array}$ \\
\hline $\mathrm{T}_{1}$ & RDF + Rhizobium & 50.3 & 28.4 & 82.8 & 56.9 & 139.7 \\
\hline $\mathrm{T}_{2}$ & $\mathrm{~T}_{1}+$ Burkholderia cepacia & 51.4 & 27.1 & 80.3 & 56.9 & 137.2 \\
\hline $\mathrm{T}_{3}$ & $\mathrm{~T}_{1}+$ Burkholderia cenocepacia & 52.4 & 26.6 & 89.1 & 64.1 & 153.3 \\
\hline $\mathrm{T}_{4}$ & $\mathrm{~T}_{1}+$ Pseudomonas fluorescens & 54.6 & 32.0 & 95.6 & 86.9 & 182.5 \\
\hline $\mathrm{T}_{5}$ & $\mathrm{~T}_{1}+$ Pseudomonas striata & 51.0 & 28.8 & 85.3 & 78.3 & 163.6 \\
\hline $\mathrm{T}_{6}$ & $\mathrm{~T}_{1}+$ Trichoderma viride & 57.8 & 35.7 & 105.2 & 91.4 & 196.6 \\
\hline $\mathrm{T}_{7}$ & $\mathrm{~T}_{1}+$ Trichoderma harzianum & 52.3 & 29.9 & 87.2 & 76.3 & 163.5 \\
\hline $\mathrm{T}_{8}$ & $\mathrm{~T}_{1}+$ Bacillus megaterium & 51.6 & 30.1 & 76.6 & 68.4 & 145.0 \\
\hline & S.E. \pm & 0.27 & 0.34 & 5.79 & 4.07 & 7.12 \\
\hline & C.D. at $5 \%$ & 0.84 & 1.05 & NS & 12.4 & 21.8 \\
\hline & C.V. \% & 5.85 & 6.45 & 11.4 & 9.73 & 7.70 \\
\hline
\end{tabular}


Table.3 Effect of phosphorus and zinc solubilizing acidifiers on content and uptake of Mn in summer soybean

\begin{tabular}{|c|l|c|c|c|c|c|}
\hline \multirow{2}{*}{$\begin{array}{c}\text { Sr. } \\
\text { No. }\end{array}$} & \multicolumn{1}{|c|}{ Treatment } & \multicolumn{2}{c|}{$\begin{array}{c}\text { Mn Content } \\
\left(\mathbf{m g ~ k g}^{-1}\right)\end{array}$} & \multicolumn{3}{c|}{ Mn Uptake (g ha $\left.{ }^{-1}\right)$} \\
\cline { 3 - 7 } & & Grain & Straw & Grain & Straw & $\begin{array}{c}\text { Total }(\mathbf{g} \\
\left.\mathbf{h a}^{-1}\right)\end{array}$ \\
\hline $\mathrm{T}_{1}$ & RDF+ Rhizobium & 73.5 & 35.3 & 113.2 & 70.6 & 183.6 \\
\hline $\mathrm{T}_{2}$ & $\mathrm{~T}_{1}+$ Burkholderia cepacia & 75.3 & 33.5 & 117.6 & 70.6 & 188.2 \\
\hline $\mathrm{T}_{3}$ & $\mathrm{~T}_{1}+$ Burkholderia cenocepacia & 76.3 & 32.7 & 129.3 & 79.3 & 208.6 \\
\hline $\mathrm{T}_{4}$ & $\mathrm{~T}_{1}+$ Pseudomonas fluorescens & 82.3 & 37.8 & 142.4 & 102.1 & 244.5 \\
\hline $\mathrm{T}_{5}$ & $\mathrm{~T}_{1}+$ Pseudomonas striata & 77.7 & 34.1 & 130.3 & 92.8 & 223.1 \\
\hline $\mathrm{T}_{6}$ & $\mathrm{~T}_{1}+$ Trichoderma viride & 84.7 & 43.7 & 154.7 & 111.9 & 266.6 \\
\hline $\mathrm{T}_{7}$ & $\mathrm{~T}_{1}+$ Trichoderma harzianum & 77.2 & 36.2 & 134.6 & 93.4 & 228.0 \\
\hline $\mathrm{T}_{8}$ & $\mathrm{~T}_{1}+$ Bacillus megaterium & 79.0 & 34.1 & 118.0 & 77.5 & 195.5 \\
\hline & S.E. \pm & 0.92 & 0.62 & 8.64 & 4.36 & 10.18 \\
\hline & C.D. at 5 \% & 2.82 & 1.92 & $\mathrm{NS}$ & 13.3 & 31.2 \\
\hline & C.V. \% & 2.03 & 3.02 & 11.51 & 8.66 & 8.12 \\
\hline
\end{tabular}

Table.4 Effect of phosphorus and zinc solubilizing acidifiers on content and uptake of $\mathrm{Cu}$ in summer soybean

\begin{tabular}{|c|l|c|c|c|c|c|}
\hline \multirow{2}{*}{$\begin{array}{c}\text { Sr. } \\
\text { No. }\end{array}$} & \multicolumn{1}{|c|}{ Treatment } & \multicolumn{2}{c|}{$\begin{array}{c}\text { Cu Content } \\
\left(\mathbf{m g ~ k g}^{-1}\right)\end{array}$} & \multicolumn{3}{c|}{ Cu Uptake $\left(\mathbf{g ~ h a} \mathbf{~}^{-1}\right)$} \\
\cline { 3 - 7 } & & Grain & Straw & Grain & Straw & $\begin{array}{c}\text { Total } \\
\left(\mathbf{g ~ h a}^{-1}\right)\end{array}$ \\
\hline $\mathrm{T}_{1}$ & RDF+Rhizobium & 28.8 & 18.6 & 44.4 & 37.2 & 81.6 \\
\hline $\mathrm{T}_{2}$ & $\mathrm{~T}_{1}+$ Burkholderia cepacia & 30.8 & 16.9 & 48.3 & 35.7 & 84.0 \\
\hline $\mathrm{T}_{3}$ & $\mathrm{~T}_{1}+$ Burkholderia cenocepacia & 33.1 & 16.0 & 56.3 & 38.9 & 95.2 \\
\hline $\mathrm{T}_{4}$ & $\mathrm{~T}_{1}+$ Pseudomonas fluorescens & 36.0 & 20.2 & 62.6 & 54.9 & 117.5 \\
\hline $\mathrm{T}_{5}$ & $\mathrm{~T}_{1}+$ Pseudomonas striata & 34.1 & 17.7 & 57.3 & 48.5 & 105.8 \\
\hline $\mathrm{T}_{6}$ & $\mathrm{~T}_{1}+$ Trichoderma viride & 39.3 & 24.1 & 72.1 & 61.8 & 133.9 \\
\hline $\mathrm{T}_{7}$ & $\mathrm{~T}_{1}+$ Trichoderma harzianum & 33.7 & 18.3 & 56.3 & 46.3 & 102.6 \\
\hline $\mathrm{T}_{8}$ & $\mathrm{~T}_{1}+$ Bacillus megaterium & 32.9 & 18.0 & 47.2 & 40.7 & 87.9 \\
\hline & S.E. \pm & 0.33 & 0.37 & 3.73 & 2.43 & 4.68 \\
\hline & C.D. at 5 \% & 1.01 & 1.13 & 11.4 & 7.76 & 14.3 \\
\hline & C.V. $\%$ & 2.86 & 3.49 & 11.6 & 9.64 & 8.02 \\
\hline
\end{tabular}

\section{Mn content and uptake in soybean crop}

The scrutiny of the data given in table 3 shows significant increase in content and uptake of Mn by soybean with inoculation of $\mathrm{RDF}+$ Rhizobium + Trichoderma viride $\left(\mathrm{T}_{6}\right)$. Significantly highest value of $\mathrm{Mn}$ content in grain $\left(84.7 \mathrm{mg} \mathrm{kg}^{-1}\right)$ and in straw $\left(43.7 \mathrm{mg} \mathrm{kg}^{-1}\right)$ were noted in treatment $\mathrm{T}_{6}$ and $\mathrm{T}_{4}$ was found at par with $\mathrm{T}_{6}$ treatment. Moreover, highest values of Mn uptake in grain (154.7 $\left.\mathrm{g} \mathrm{ha}^{-1}\right)$ and straw (111.9 $\left.\mathrm{g} \mathrm{ha}^{-1}\right)$ were noted in treatment $\mathrm{T}_{6}$ and $\mathrm{T}_{4}$ (Rhizobium + Pseudomonas fluorescens) was found at par with $\mathrm{T}_{6}$. Soliman et al., (2012) revealed that Mn concentration in grain and straw of safflower was influenced significantly noted highest receiving 100\% NPK + FYM @ 5 Mg 
$h^{-1}$. Due to integrated use of organic and inorganic fertilizers acceleration of availability of nutrient in soil ultimately resulted in more utilization and assimilation of Mn. Gurumurthy et al.,(2009) also reported that the concentration of $\mathrm{Mn}$ was noticed higher in $50 \% \mathrm{RDF}(\mathrm{N}$ - applied through Urea) $+50 \% \mathrm{~N}$ applied through $F Y M+P S B$ in soybean.

Altomare et al., (1999) concluded that the iron and manganese have been particular foci of studies on their solubilization by soil microflora, their availability to plants, while plant roots can take up chelated iron either directly or after reduction of $\mathrm{Fe}^{3+}$ by plasma membrane reductases. Manganese can occur in several oxidation states, but it is available to plants only in the reduced form $\left(\mathrm{Mn}^{2+}\right)$ and the activity of rhizosphere microorganisms that can either oxidize or reduce manganese and thus influence its availability. Microbes having the potential of synthesizing plant hormones might be responsible for expansion of root surface area and enhanced plantmicrobe interaction resulted in more nutrient uptake (Qureshi et al., 2005). Soliman et al., (2012) reported that $\mathrm{Mn}$ concentration in grain and straw of safflower was influenced significantly in treatment receiving $100 \%$ NPK + FYM @ $5 \mathrm{Mg} \mathrm{ha}^{-1}$.The increase in Mn uptake with application of FYM and NPK might be due to steady supply of Mn through organics. Sawarkar et al., (2010) also noted that the application of $100 \%$ NPK + FYM showed highest $\mathrm{Mn}$ uptake by soybean in Vertisol.

\section{Cu content and uptake in soybean crop}

The data narrated in table 4 revealed that the content and uptake of $\mathrm{Cu}$ by soybean crop was also increased with inoculation of Rhizobium + Trichoderma viride along with recommended dose of fertilizers. Significantly highest values of $\mathrm{Cu}$ content in grain $(39.3 \mathrm{mg}$ $\left.\mathrm{ha}^{-1}\right)$ and straw $\left(24.1 \mathrm{mg} \mathrm{ha}^{-1}\right)$ were noted in treatment $\mathrm{T}_{6}$ and $\mathrm{T}_{4}$ was found at par with $\mathrm{T}_{6}$ treatment. Significantly highest values of $\mathrm{Cu}$ uptake in grain $\left(72.1 \mathrm{~g} \mathrm{ha}^{-1}\right)$ and straw $(61.8 \mathrm{~g}$ $\mathrm{ha}^{-1}$ ) were noted in treatment $\mathrm{T}_{6}$ and $\mathrm{T}_{4}$ (Rhizobium + Pseudomonas fluorescens) was found at par with $\mathrm{T}_{6}$ treatment. Sayad et al., (2009) reported that $\mathrm{Cu}$ uptake in grain and straw at harvest of safflower crop was influenced significantly with $100 \%$ NPK + FYM @ Mg ha ${ }^{-1}$.Similar findings were reported by Soliman et al., (2012). Gurumurthy et al., (2009) noticed that the concentration of $\mathrm{Cu}$ was higher with $50 \%$ $\mathrm{RDF}(\mathrm{N}-$ applied through Urea) $+50 \% \mathrm{~N}$ applied through $F Y M+P S B$ in soybean grain and straw. An increased nutrient uptake was observed $100 \%$ RDF+ dual inoculation treatment as a consequence of better nutritional environment offered through the cumulative effect of inorganic sources of nutrients through biofertilizers (Kumar et al., 2009). Higher biomass production may also be the most pertinent reasoning for higher uptake of nutrients in the treatments referred above.

Sayad et al., (2009) reported $\mathrm{Cu}$ concentration in grain and straw at harvest of safflower crop was influenced significantly and highest values were recorded with receiving 100\% $\mathrm{NPK}+\mathrm{FYM} @ \mathrm{Mg} \mathrm{ha}^{-1}$.With the increment in supply of essential elements through organic and inorganic sources, their availability, mobilization and influx into plant tissue and improving content and uptake in the crops. Murthy et al., (2012) found the uptake of $\mathrm{Cu}$ by safflower was higher in the recommended dose of $\mathrm{N}, \mathrm{P}$ and $\mathrm{K}$ with farmyard manure than other treatments.

\section{References}

A.O.A.C. (1993) Official Method of Analysis, Ed. 12, Association of Official Analytical Chemists, Washington, D.C. 
Altomore, C., Norvel, W.A., Biorkman and Harman, G.E. (1999). Solubilization of phosphates and micronutrients by the plant growth promoting and biocontrol fungus. Trichoderma harzianum Rifai. Appl. Environ. Microbial, 65(7): 292629.

Amalraj D.L., Maiyappan S. and John Peter A. (2012). In vivo and In vitro studies of Bacillus megaterium var. phosphaticum on nutrient mobilization, antagonism and plant growth promoting traits. $J$. Eco. Biotechnology, 4 (1): 35-42.

Anonymous, (2014).Estimates of area, productivity and production of soybean in India during kharif 2014.www.sopa.org/crop-po.doc.

Chand, S. and Somani, L.L. (2003). Balance use of fertilizers, organics and biofertilizer in mustard. Int. J. Trop. Agric., 21(1-4): 133-140.

Gurumurthy, K. T., Leena Narayana and Prakasha, H.C. (2009). Micronutrient uptake and yield of soybean (Glycine $\max$ (L) Merrill) as influenced by integrated nutrient management practices. Mysore J. Agric. Sci., 23(4): 883-886.

Jackson, M.L. (1967). Soil Chemical Analysis. Prentice Hall of India Private Ltd., New Delhi, pp 38-214.

Jackson, M.L. (1973). Soil Chemical Analysis. Prentice Hall of India Private Ltd., New Delhi. pp: 498

Kumar, R.P., Singh, O.N., Singh, Y., Dwivedi, S. and Singh, J.P. (2009). Effect of integrated nutrient management on growth, yield, nutrient uptake and economics of Frenchbean (Phaseolus vulgaris). Indian J. Agric. Sci., 79(2): 122-128.

Mekki, B.B., Selim, M.M. and Saber, M.S.M. (1999). Effect of organic manuring, chemical and biofertilizers on yield and nutrient content of millet grown in newly reclaimed soil. Egyptian $J$.
Agron. 21: 113-124.

Murthy, I. Y. L. N., Padmawathi, P. and Haripriya, C. H. V. (2012). Critical limits of boron for safflower (Carthamus tinctorius L.) grown in semi-arid Vertisol. J. Oilseed Res., (29, Spl. Issue): 310-311.

Panse, U.G. and Sukhatme, P.V. (1985).Statistical Methods for Agricultural Workers. I.C.A.R. Pub., New Delhi. pp: 600-604.

Plummer, D. (1998).An Introduction to Practical Biochemistry, $3^{\text {rd }}$ Ed. Tata McGraw Hall, Publication, Delhi.

Qureshi, A.A. and Narayanasamy, G. (2005). Residual effect of phosphate rocks on the dry matter yield and $\mathrm{P}$ uptake of mustard and wheat crops. J. Indian Soc. Soil.Sci., 53(1): 132-134.

Rahman, L. (1982) Cultivation of soybean and its uses. City Press, Dhaka: 5-7.

Saravanan,V. S., Madhaiyan, M. and Thangaraju, M., (2007). Solubilization of zinc compounds by the diazotrophic, plant growth promoting bacterium Gluconacetobacter diazotrophicus. 66:1794-98.

Sarawagi, S.K., Tiwari, P.K. and Tripathi, R.S. (1999). Uptake and balance sheet of nitrogen and phosphorus in gram (Cicer arietinum) as influenced by phosphorus, biofertilizer and micronutrients under rainfed condition. Indian J. Agron., 44(4): 768-772.

Sawarkar, S.D., Thakur, R. and Khamparia, R.S. (2010). Impact of long term continuous use of inorganic and organic nutrients on micronutrients uptake by soybean in Vertisol. J. Soils and Crops, 20 (2): 207-210.

Sayad, G., Majid Afyuni, Sayed Farhad Mousavi, Karim C. Abbaspour, Richards, B.K. and Rainer Schulin, (2009). Effects of cadmium, copper, lead, and zinc contamination on metal accumulation by safflower and wheat. 
Soil and Sediment Contamination, 54: Tabatabai, M.A. and Bremner, J.M. 216-228

Soliman, A.H., Abeer A. Mahmoud and Gendy, A.S.H (2012). Effect of foliar fertilizers on growth, yield and active ingredients of safflower plant under sandy soil condition. J. Appl. Sci. Res., 8 (11): 5572-5578 (1970).Use of P. nitrophenyl phosphate for assay of soil phosphates activity. Soil Biol. Biochem., 1: 301-307.

Thimmaiah, A. (2000). Standard Methods of Biochemical Analysis. Kalyani Publishers, New Delhi. pp: 388-391.

\section{How to cite this article:}

Kranthi Kumar, B., Syed Ismail, K. Manasa and Anuradha Pawar, K. 2017. Effect of Phosphorus and Zinc Solubilizing Acidifiers on Content and Uptake of Micro nutrients in Summer Soybean. Int.J.Curr.Microbiol.App.Sci. 6(6): 2784-2791. doi: https://doi.org/10.20546/ijcmas.2017.606.331 